\title{
Test Analysis Of The Development Conversion And Recognition Prior Learning Models On Vocational Teachers' Education
}

\author{
Fuad Abdillah, Slamet PH, Sukardi
}

\begin{abstract}
This study aims to: (1) develop a conversion and recognition of prior learning (RPL) model on the vocational teachers' education in the field of automotive engineering: (2) determine the software quality developed by the functional suitability, efficiency of performance, compatibility, usability, reliability aspects, maintainability, portability, and security testing based on ISO 25010. The method applied in this Research and Development $(R \& D)$ is the Brogg and Gall. The results of the study revealed that: (1) the conversion and prior learning recognition (RPL) models on vocational teachers' education were in accordance with the requirements of the field (2) Test results on the functional suitability scored 10.5 and a mean of 3.45; the efficiency of performance had a score of 9.5 and a mean of 3.15; compatibility scored 8 with a mean of 4; the usability had a score of 19.5 and mean of 3.2; while the reliability aspect had a score of 13.5 and a mean score of 3,37. Furthermore, the conversion and prior learning recognition models are flexible in use and competent. Regarding the portability aspect, it is compatible with Mozilla Firefox, Google Chrome, and Internet Explorer browsers. It is free from XSS and SQL injection vulnerabilities seen from the security information system.
\end{abstract}

Keywords-Vocational Teachers' Education, Test Conversion and Recognition of Prior Learning Model

\section{INTRODUCTION}

The key problems vocational teachers face is directly related to problems of vocational high schools. The key to educational success is the vital role the teacher plays in the process of knowledge transfer to students. This is in accordance with Kartadinata's statement (2010); he states that "one of the key indicators of educational quality is the quality of teachers." The roles of teachers are very vital for the success of the entire learning process. (Jones, Jenkin \& Lord, 2006: 1).

The fundamental problems of vocational teachers in Indonesia are related to problems of number, distribution, relevance, and quality. In accordance with the data center and DIKBUD statistics in 2015/2016, the current number of vocational teachers in Indonesia is about 260,694 and this value increases constantly as the number of vocational students increase. Furthermore, the number of vocational schools has grown from 10,256 schools in 2011/2012 to about 12,659 schools in 2015/2016 (18.9\% growth). This is

Revised Manuscript Received on April 19, 2019.

Fuad Abdillah, Vocational Education S3 Doctoral Program, Yogyakarta State University Yogyakarta, Indonesia (Email: Fuadabdillah88@gmail.com)

Slamet PH, Faculty of Engineering, Yogyakarta State University,Yogyakarta, Indonesia(Email: Slamet PH@uny.ac.id)

Sukardi, Faculty of Engineering, Yogyakarta State University, Yogyakarta, Indonesia (Email: Sukardi@uny.ac.id) in line with the increase of registrants and new students in vocational high schools by $11.7 \%$ in $2015 / 2016$.

The rising number of vocational schools and new students should be supplemented by equally increasing numbers of vocational teachers. Furthermore, from the insufficient vocational teachers, the adaptive teachers were $78 \%$ or 126,599 and the productive teachers were only about $22.3 \%$ or 35,057 in 2015/2016. Meanwhile, the number of Vocational High School (SMK) teachers without S1qualification is 20,684 or $7.8 \%$ in $2015 / 2016$ and 16,686 in 2016/2017 or $6.0 \%$. (DIKBUD Data and Statistics Center: 2016)

In order to overcome the insufficiency of vocational teachers, various methods have been applied. One of them is through recruiting productive teachers from Diploma III / polytechnic graduates. However, this contrasts the provisions in Constitution No. 14 in 2005 concerning teachers and lecturers. It stated that the minimum academic qualification of vocational teachers were S1 / Diploma IV. However, because of their work experience in the industrial sector, most of the DIII / polytechnic graduates were obligated to take the jobs on. They are considered to have the required vocational competencies even though they have no pedagogic experience.

Actually, a lot of efforts have been put in by the government to increase the number of teachers and to improve academic qualifications especially for vocational teachers, e.g. through implementation of an educational degree program for in-service teachers (SKGJ) and through Work Experience Recognition and Learning Outcomes (PPKHB). This is in accordance with Regulation No. 58 of 2008 of the Ministry of Education and Culture.

However during its implementation, it showed a lot problems. According to Pusbangprodik M \& E report in 2012, it stated that obstacles were encountered in implementing The Work Experience Recognition and Learning Outcomes (PPKHB), namely: 1) the improper functionality of the online network system 2) the lack of interest from PPKHB candidate teachers 3) the incompatibility of the interested candidates and the offered study program 4) the disagreement between LPTKs in determining the amount of PPKHB given to participants of the program 5) not all LPTKs are willing to implement the program 6) treating the core curriculum by DIKTI in the SKGJ program has an impact on SKS recognition. 
This solutions to the educational obstacles should be applied in both educational institutions and educational personnel. It can be carried out through the mechanism of the learning equalization program, either through formal or informal education. The development is done with compiling course conversions software and the recognition of the prior learning by using a web-based information platform - www.repela.org

\section{RESEARCH METHODOLOGY}

This study made use of Research and Development ( R \& D) methods, Brogg and Gall (1986: 570) Furthermore, Richey \& Nilson (1996: 122) stated that the research development is oriented on the product development. It is described as accurately as possible before final product evaluation.

Gay also expressed the same thing (1990: 10). He states that the research development is not used to test the hypotheses, rather, to produce a product to be effectively utilized in educational institutions. The product here refers to the computer software used in preparing course conversions and the website used in recognizing prior learning. The Research and Development design in this study starts from a study of the lack of educational undergraduate teaching programs through recognition of work experience and learning outcomes (PPKHB) in LPTK. The results of the study were used to develop a new product.

\section{A. Development Procedure}

The first developmental procedure used a descriptive qualitative (explorative) approach by collecting data with emphasis on the descriptions of people and places. It focused on the evaluation of SKGJ program implementation on LPTK which was appointed as the organizer by the government. The second step is the model development to produce a conversion model prototype and RPL in the form of media / helping tools online (www.repela.org). It is completed by the instrumental research and the testing mechanism. After developing the software, the quality analysis based on ISO 25010 quality model was carried out. It involves the functional suitability, usability, efficiency of performance, portability, and security analysis. The model was taken based on the web quality dimensions.

After identification of the problem, the next step is to collect data by observation, literature study, and interview. The software design is in the form of Entity Relationship Diagram (ERD) and Unified Modeling Language (UML), namely; Use Case, Activity, Sequence and Class Diagram.

The next step is the examination and implementation of the unit. The product testing is conducted to determine the quality of the software across all aspects. If the results are not in accordance with the standard, the product will be revised. The usage test was conducted with beta testing and demonstration. Furthermore, it continued with the usability testing using the System Usability Scale (SUS) questionnaire. If the results are as expected, the last stage is the implementation of products. It is the finalization and a wider trial involving the three LPTKs in Central Java and Yogyakarta.

\section{B. Research Subjects and Research Sites}

The research subjects for usability are the respondents from candidates, study program admin, and program implementers / lecturers. The subjects for functional suitability testing are five respondents. They are program managers / lecturers, candidates, assessors, administrators and IT experts.

\section{Methods and Instruments}

The observation method is carried out to obtain the test data on performance efficiency, portability, and security. The questionnaires are in form of a test case for the functional suitability testing with Likert scale. The functional suitability testing was carried out to ensure the specifications run well (Nidhra, Srinivas, and Dondeti, Jagruth: 2012). It used a test case based on the result analysis of the user's needs.

Furthermore, the usability testing used SUS questionnaires for 64 respondents. The testing of the efficiency of performance used the GTMetrix tool to determine Yslow scores, Page speed and time required to complete the conversion and recognition process. Then, the portability testing is done using the Web (Browser) Compatibility Testing Framework (Kaalra \& Gowthaman, 2014). It used Mozilla Firefox, Google Chrome, and Internet Explorer browsers. The security testing is carried out using w3af software to test vulnerabilities to Cross-Site Scripting (XSS) and SQL Injection.

\section{Data Analysis Technique}

The data analysis technique in this study is the data results from the black box testing to answer the question "whether the conversion and prior learning recognition model on vocational teacher's education is effective, practical and workable." Meanwhile, the results of the tests were conducted by IT experts and users to descriptively analyze the answer to the question "How big is the level of effectiveness, efficiency, and practicality of the model?"

The data mechanism analysis carried out on the functional suitability aspect is declared feasible if all functions run correctly. All functions in the test case are valid for all correspondents. In the usability aspect, the calculation is done to obtain the SUS score. The scores above 68 are considered above average while scores below 68 are considered below average (Jeff Sauro, 2011). Then, it could be declared feasible if the score is above 68. The efficiency of performance analysis technique is done by finding the average of Yslow and Page speed scores. According to Nielsen, Jakob (1993), 10 seconds is the time limit for keeping the user's attention to the dialog (webpage). The response time is declared as good if it is less than 10 seconds. In the portability testing, the system is declared compatible if the system runs as expected across the browsers. Next, in the security testing, the criterion is feasible if the system is free from XSS and SQL Injection vulnerabilities. 


\section{RESULT AND DISCUSSION}

The results of the user needs analysis is divided into three actors based on its roles in the system. They include; the program admin, assessors and candidates. The program admin has three functions which are managing, assisting for physical evidence, and announcements. The assessor has the function of managing the program, verifying requests from candidates and deciding the number of credits that are recognized. The system design uses the Unified Modeling Language (UML), Entity Relationship Diagram, and the user interface design. The ERD design is shown in Figure 1, 2 , 3. which sequentially shows the case use diagram for program admins, assessors, and candidates.

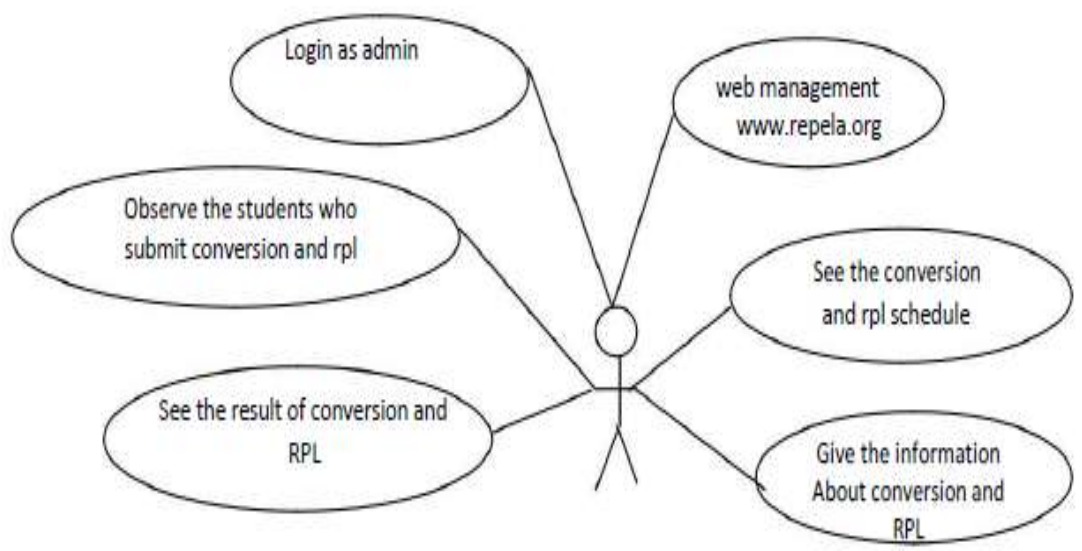

Program Studi admin

Fig. 1. Use Case Program Study Admin

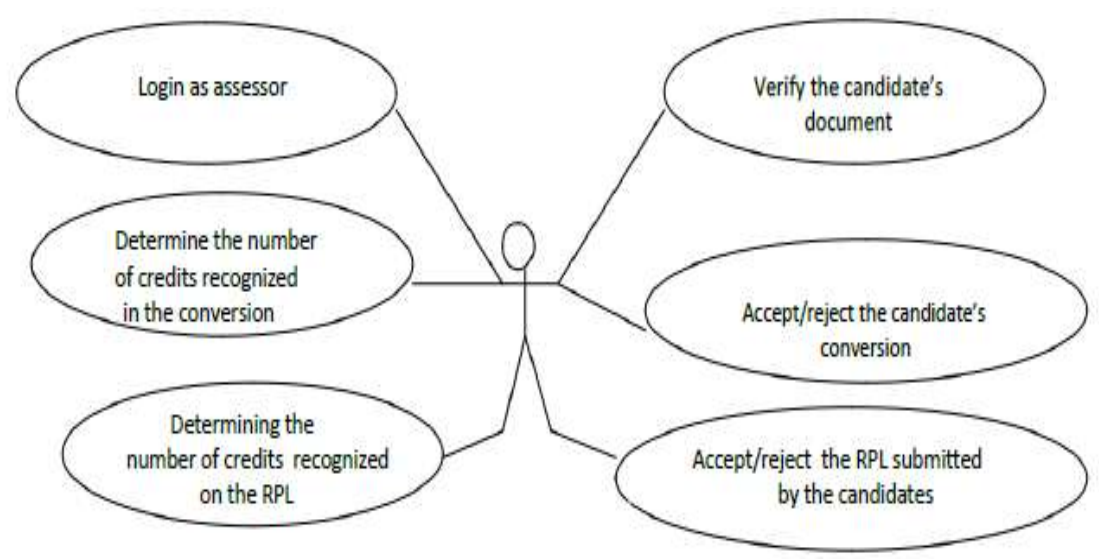

Assessor

Fig. 2. Use Case of assessor lecture

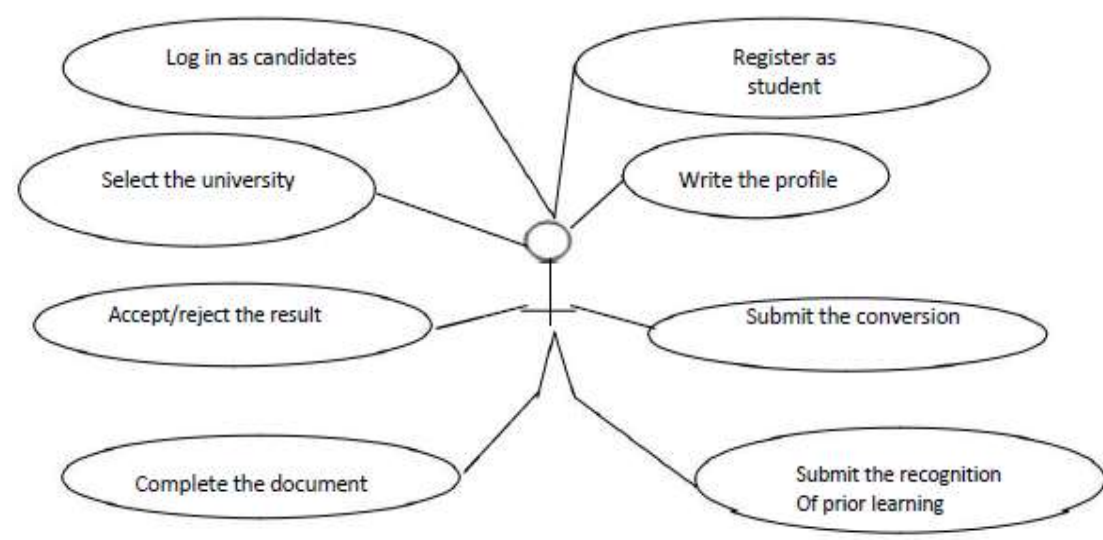

Candidate

Fig. 3. Use Case of Candidate 
The system implementation used the PHP programming language with the Codeigniter framework version 3 . The database used is Postgresql with the Ubuntu 14.04 linux operating system. The implementation of user interfaces is carried out using HTML and JavaScript. Figure 4 shows the www.repela.org dashboard for the master admin.

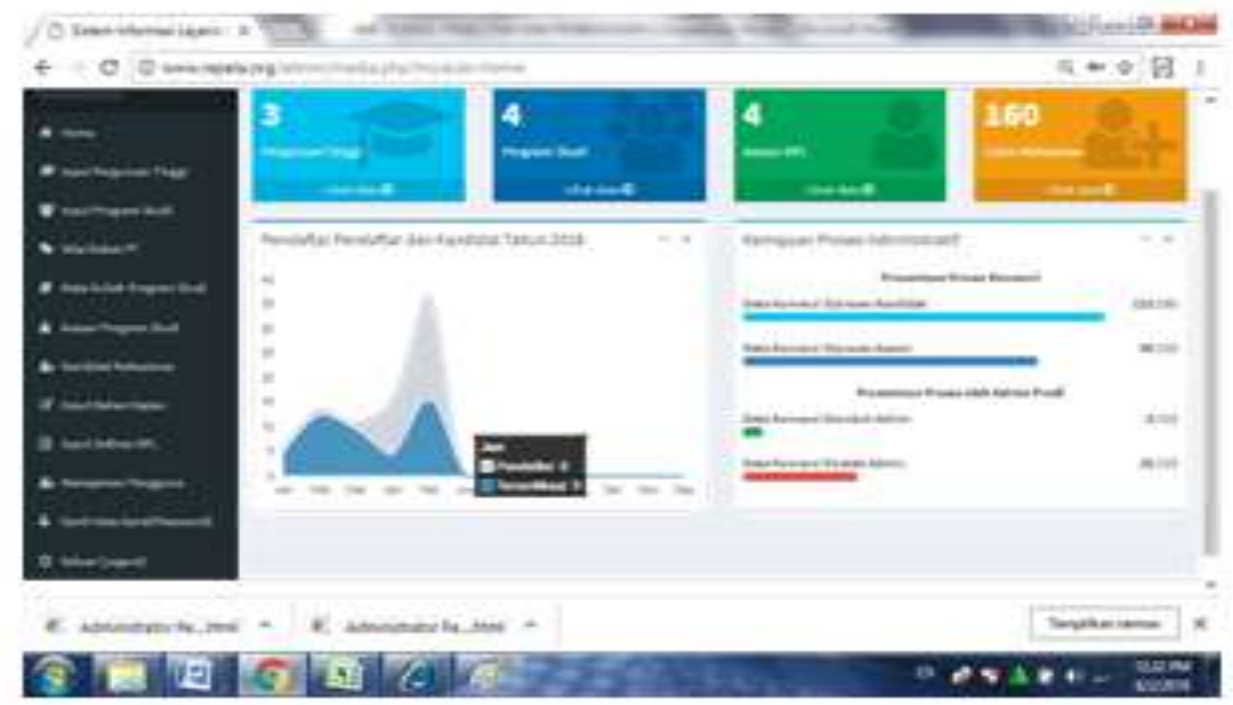

Fig. 4. Dashboard for the master admin end; no errors were shown (bugs). After development of the system, it is tested based on the five characteristics of the ISO 25010 quality model. The functional suitability is carried out using a test case by assessors, candidates and the expert programmers. Its test results show that all functions run as expected.

Then, the usability testing obtained an average score of SUS 81.63. It is above average and categorized as good. The testing of the efficiency of performance obtained a Pages peed score of 92.75 and Yslow score of 84.13 with an average response time of 1.08 seconds (good).

Furthermore, the portability testing is done by observations with different browsers. The observations are classified according to ACR (Application Compatibility Report). The results revealed that the conversion and recognition of prior learning model on a web-based vocational teachers' education was compatible with the browsers used in the study. The security testing was done using the w3af tool to determine vulnerabilities to CrossSite Scripting and SQL Injection attacks. The result showed that there were no vulnerabilities found in XSS and SQL Injection. Therefore this system is categorized as a green application.

\section{CONCLUSION AND SUGGESTION}

\section{A. Conclusion}

Based on the results and discussion, it can be concluded that the conversion and recognition of prior learning model on the vocational teachers' education in the automotive field is in accordance with the users' need. The software quality testing used the ISO 25010 quality standards on the functional suitability, usability, efficiency of performance, portability, and security aspects. In the functional suitability aspect, all functions in the system ran well. In the usability aspect, the SUS score is 81.63 , which is above the average. For the aspect of efficiency of performance, the Page speed
The test was carried out using the PHP unit tool and in the

score was 92.75 and the Yslow score was 84.13. It means that the response time for all pages is 1.08 seconds and it is categorized as good. In the portability testing, it is known that the conversion and recognition models were compatible in Google Chrome and Mozilla browsers.

\section{B. Suggestion}

The conversion and recognition of prior learning models should be additionally developed for mobile platforms. Furthermore, the web pages should be more responsive to display on smaller screen sizes for an easier access to users such as candidates, assessors, study program admins, and other visitors through smartphones and tablets.

\section{REFERENCE}

1. Agarwal, B. B.; Tayal, S.P.; Gupta, M. (2010). Software Engineering \& Testing. Sudbury, Massachusetts: Johanes and Bartlett Publishers Borg, W.R. \& Gall, M.D. Gall. (1983). Educational Research: An Introduction, Fifth Edition. New York: Longman.

2. International Organization for Standardization. (2011) ISO/IEC 25010. Diakses dari http://www.iso.org/iso/catalogue_detail.htm? csnumber=35733. pada tanggal 01 November 2015.

3. Kaalra, B., \& Gowtman, L. (2014). Browser Compatibility Testing Using Manual Testing Methods and Test Tools. International Journal of Advanced Studies in Computer Science and Engineering, Volume 3 , Issue 10

4. Kementerian Pendidikan dan Kebudayaan. (2016,) Pusat Data dan Statistik Pendidikan dan Kebudayaan , Statistik Sekolah Menengah Kejuruan (SMK) 2015/2016

5. Munassar, N., M., A., \& ovardhan, A. (2010). A Comparison Between Five Models Of Software Engineering. International Journal of Computer Science Issues, Vil. 7, Issue 5, September 2010

6. Nielsen, Jakob. (1993). Response Times: The 3 Important Limits. Diakses dari 
https://www.nngroup.com/articles/responsetimes-

$3-$ important-limits/. pada tanggal 01 November 2015.

7. Nidhra, Srinivas, and Dondeti, Jagruthi, 2012, Blackbox and Whitebox Testing Techniques - A Literature Review, International Journal of Embedded Systems and Applications (IJESA) Vol.2, No.2, June 2012

8. Rosa A.S \& M. Shalahuddin. (2011). Rekayasa Perangkat Lunak (Terstruktur dan Berorientasi Objek). Bandung: Modula. Sauro, Jeff. (2011). Measuring Usability with the System Usability Scale (SUS). Diakses dari http://www.measuringu.com/sus.php pada 01 November 2015.

9. Mustaqbal S, Firdaus RF, Rahmadi H, (2015) Pengujian Aplikasi menggunakan black box testing boundary value analysis. Jurnal Ilmiah Teknologi Informasi Terapan Volume I, No 3, 10 Agustus 2015 